\title{
CHILDHOOD EDUCATION
}

\section{March 22, 2004 \\ (No. 3, Vol. 80; Pg. 116; ISSN: 0009-4056 IAC-ACC-NO: 114008352) \\ The Dynamics of Families Who are Homeless: Implications for Early Childhood Educators}

\author{
By Kevin J. Swick
}

Family homelessness has emerged as a serious global problem (Stronge, 2000). Over the past 25 years in the United States, the makeup of the homeless population has changed significantly. As De Angelis (1994) reports:

The landscape of homelessness has changed since the early1980s, when nearly all homeless people were men. Today, families - typically women with two children under age 5 make up 30 percent of the homeless population. (p. 1)

Some scholars (e.g., Bassuk, 1991) suggest that families may constitute 40 to 50 percent of the homeless.

Thus, the focus of this article is on articulating the various dynamics of families who are homeless, what this means for the early childhood education profession, and what strategies we can employ to effectively support homeless families with young children.

The Changing Concepts of Homelessness Various government and private agencies have different concepts of homelessness. The U.S. federal government defines homeless individuals as:

those who lack a fixed, regular, and adequate nighttime residence; have a primary nighttime residence that is

- a supervised publicly or privately operated shelter designed to provide temporary living accommodations (including welfare hotels, congregate shelters, and transitional housing for the mentally ill);

- an institution that provides a temporary residence for individuals intended to be institutionalized; or

- a public or private place not designed for, or ordinarily used as, a regular sleeping accommodation for human beings. (cited in Heflin, 1991, p. 1) 
Regarding children and youth, the McKinney-Vento Homeless Education Assistance Act, Section 725 (as cited in National Coalition for the Homeless, 1999) states, "Homeless children and youths ..."

a) means individuals who lack a fixed, regular, and adequate nighttime residence (within the meaning of section 103(a)(1); and

b) includes -

(i) children and youths who are sharing the housing of other persons due to loss of housing, economic hardship, or a similar reason; are living in motels, hotels, trailer parks, or camping grounds due to the lack of alternative adequate accommodations; are living in emergency or transitional shelters; are abandoned in hospitals; or are awaiting foster care placement;

(ii) children and youths who have a primary nighttime residence that is a public or private place not designed for or ordinarily used as a regular sleeping accommodation for human beings (within the meaning of section 103(a)(2)(c);

(iii) children and youths who are living in cars, parks, public spaces, abandoned buildings, substandard housing, bus or train stations, or similar settings; and

(iiii) migratory children (as such term is defined in section 1309 of the Elementary and Secondary Education Act of 1995) who qualify as homeless for the purposes of this subtitle because the children are living in circumstances described in clauses (i) through (iii). (p. 8)

The concept of homelessness continues to change, as many families that are not technically defined as homeless have all of the attributes of being homeless. For example, it is common among many families that are chronically poor to double- or triple-up with each other in order to survive, financially. In nations with high rates of poverty, it is common for three or more families to live in very small areas (Bellamy, 2003).

Women and children now represent up to one-half of the homeless population in many cities (National Coalition for the Homeless, 1999). When families with older children and adolescents are included in the count, over 50 percent of the homeless population is families (Shane, 1996). Vissing and Diament (1997) Indicate that the problem is likely to be more serious than the statistics indicate; many adolescents who are homeless avoid the label, fearing the stigma it may give them with their peers, and so may not be represented in the statistics. Furthermore, many children in foster care are "housing displaced"; that is, no longer able to live in their home of origin (Toth, 1997). Another dynamic in this complex situation is that a large number of working families live on the edge of homelessness, due to low-paying jobs and high expenses (Heyman, 2000). 
Homelessness of children and youth is particularly tragic. Estimates indicate that 1 to 3 million children and adolescents in the United States are homeless (National Coalition for the Homeless, 1999). The impact of child and family homelessness on society is even greater when one considers the resultant problems being passed from one generation to the next. As Vissing (1996) notes, children learn what they observe, and when their most consistent experiences are within chronically poor, powerless, and homeless situations, they are bound to acquire many of the attitudes that go with being powerless.

Family homelessness is not necessarily a factor of socioeconomic status. Even middle- and upper-income mothers and children are not immune from homelessness. Physical, sexual, and psychological abuse destroys the family system of many economically advantaged women and children (Shane, 1996). Women may escape from an abusive home environment to protect themselves and/or their children, or they may be forcibly evicted by their spouse or friend (Peled, Jaffe, \& Edleson, 1995).

Indeed, many people now become homeless because of abuse, natural disasters, and other trauma. The widening income gap between the poor and the rich and the increasing cost of raising children are also key factors (Coontz, 1995). Furthermore, war, famine, and disease have led to dramatic increases in family homelessness throughout the world (Bellamy, 2003).

Diverse and Unique Situations of Homeless Families

The situations that lead to homelessness for families and children/adolescents range from leaving an abusive relationship, eviction for failure to make rent payments, running away from parents, or being displaced because of unsafe housing (Bassuk, 1991; Heyman, 2000).

Families that are homeless are distinct from individuals who are homeless. For example, De Angelis (1994) and Bassuk, Browne, and Buckner (1996) report that homeless families typically have much lower levels of substance abuse and mental health problems than do homeless individuals. It is also noteworthy that homeless women with children are usually homeless for shorter periods and are more actively engaged in strategies to empower themselves (Morris, 1998). They are also more likely to be employed and less likely to engage in antisocial behavior (Edin \& Lein, 1997).

Homeless mothers also have unique situations. Some homeless mothers have all their children with them; some have one child with them and have placed the others with a relative or friend (many shelters will not accept adolescents); in some cases, the children have been placed in the state's custody (Dail, 1990).

In yet other cases, the children may be in foster care (Shane, 1996; Toth, 1997) or in the state reform system (Ayers, 1997). Inclusion of these populations of "society's children" in homeless statistics would certainly increase the number of people classified as homeless. Also, "housed" children - who have a place to go home to, but who basically live on the streets without any adult supervision are often in worse condition than many homeless children (Berck, 1992).

The Dynamics of Families Who are Homeless: Implications for Early Childhood Educators 
Dail (1990) and Edin and Lein (1997) explicated the characteristics of women who are homeless, showing the diversity of these situations: 50 percent are between 17 and 25 years of age; a majority have never married, or are separated, divorced, or widowed; more than 50 percent have completed high school; and 75 percent have been employed at some point in their life (Buckner, Bassuk, \& Zima, 1993).

As Dail (1990) suggests, the etiology of family homelessness is based in three areas of difficulty:

- A crisis, often of a violent nature, in a relationship with a male

- A prior crisis in the family of origin - sexual abuse, abandonment, parental death, or chronic neglect

- A consistent problem with mental illness and/or drug abuse.

While the situation of each homeless mother is unique, abuse, severe depression, chemical dependency, illiteracy, and chronic poverty are common contributing factors (Nunez, 1996).

The particular situation and complexities a homeless family faces will determine the type of services and assistance they need. For example, a middle class homeless mother who is seeking shelter from an abusive spouse may need a combination of short-term services with counseling for longer range needs. More intensive services are likely to be needed for the chronically poor and persistently homeless family (Wasson \& Hill, 1998).

Early childhood educators can empower homeless mothers by building on their strengths. For example, homeless women with children appear to be more proactive than homeless women in general, and more so than chronically poor women who are not homeless (De Angelis, 1994). It appears that women who seek shelter and other support services for their children are more connected with sources of support in the community (Bassuk, 1991; Swick \& Graves, 1993).

Success stories of homeless women and their children in attaining more self-sufficiency indicates that paying attention early on to homelessness in young families is crucial (Shane, 1996). In contrast, the prevalence of many poor "housed" families that live in violent and abusive environments indicates a pathology of isolation and neglect (Bassuk, Browne, \& Buckner, 1996). Evidence suggests that homeless women with children "are the most likely to have finished high school and to have the lowest average of adult arrests" (De Angelis, 1994, p. 1). It also has been noted that homeless mothers are more likely to be gainfully employed than homeless women in general (Bassuk, Browne, \& Buckner, 1996).

The observation that many housed but chronically poor women with children are more symptomatic of dysfunction than are classified homeless mothers (particularly those mothers with children in shelters or transitional housing) highlights the need for reconceptualizing "homelessness" within a broader context. The research suggests that American society has a large number of "hidden homeless families" that need the intensive services being provided for some homeless families (Swick, 1997).

The Dynamics of Families Who are Homeless: Implications for Early Childhood Educators Page 4 of 10 
Implications for Early Childhood Professionals: Relating and Responding to Family Homelessness

Early childhood professionals seeking to support homeless families should:

1) develop an ecological understanding of family homelessness; 2) develop responsive and supportive attitudes and behaviors; 3 ) create an inviting and validating center or school culture; 4) engage parents and families in all aspects of their children's learning and development; and 5) empower parents and families through adult education, job enhancement, and related family literacy (Nunez, 1996; Nunez \& Collignon, 2000; Swick, 1997).

Develop an Ecological Understanding of Family Homelessness. The ecological framework theory emphasizes the influence of actions and events on people, and the transactive nature of the different "systems" in which people live (Bronfenbrenner, 1979). A basic construct of this perspective is that human development and learning are the result of dynamic interactions between people and their environment.

Three important elements can help early childhood professionals better understand the dynamic nature of family homelessness:

- The individual's system influences and is influenced by his or her interactive involvement in the various contexts of life. For example, comprehensive job support and training services, provided within a homeless shelter program, can improve mothers' job prospects (Nunez, 1996).

- Each system plays a role in the evolving life of human beings. As noted by Swick and Graves (1993), homeless families resolve their stressors most effectively when all systems are supportive and empowering.

- Whatever happens within and between systems influences people's functioning (Bronfenbrenner, 1979). For example, Powell (1998) indicates that quality child care affects parents' self-confidence and thus creates new possibilities for the family.

Develop Responsive and Supportive Attitudes and Behaviors. Swick and Graves (1993) emphasize that early childhood professionals need to first develop positive and supportive perspectives and behaviors toward families. They note four key elements of this process:

- Nurture and renew positive, supportive, and responsive attitudes and relationship patterns with parents and families.

- Seek to understand parent and family situations from the parental view first, so that you have the family's idea of what is important.

- Recognize and value the role of the parent and family.

- Model positive attitudes and behaviors to parents and families.

The Dynamics of Families Who are Homeless: Implications for Early Childhood Educators 
Create an Inviting and Validating Center or School Culture. "Homeless students and their parents develop their 'schema' of what schools are through direct experiences, including the messages they receive related to access and participation in social and educational activities" (Swick, 2000, p. 165).

- Early childhood programs can foster an inviting atmosphere for homeless families by:

- Providing immediate and friendly access to basic human services

- Treating everyone in the center or school with respect, and making sure their ideas are represented in the fabric of the program

- Involving homeless families in shaping program goals and strategies, allowing them to take on ownership of the program

- Providing comprehensive services (such as adult education and family literacy practices), and being sure these services are family-friendly.

Engage Parents and Families in All Aspects of Their Children's Learning and Development. As Powell (1998) suggests, early childhood professionals need to develop and continually refine an "engagement, participatory" stance in relation to the involvement of homeless families. Quint (1994) notes that educators should begin this process during their initial contact with parents and families. Find out what parents believe is key to minimizing the stressors affecting them and their children. One school invites parents and children to list their top concerns about their lives and then integrates these issues into the plans for helping the families (Nunez, 1996).

Another important construct is that of engaging parents in positively relating to their children (Anooshian, 2000). Positive parent-child relations serve as a buffer to many stressors that otherwise can impede the learning and functioning of children and families (Stronge, 2000).

An extension of the parent-child relationship lies in the partnership between parents and teachers; in particular, home learning activities can empower the entire family (National Coalition for the Homeless, 1999). This partnership process can begin with early childhood educators providing critical home learning resources and community support in shelters and libraries.

It is also important that parents and families have regular opportunities to "educate" professionals about needed literacy and other support resources. Simple items like paper and pens, a quiet place to study, help for parents to understand the material being studied, and guidance on strategies parents can use to help their children are essential.

Empower Parents and Families Through Adult Education, Job Enhancement, and Related Family Literacy. The most empowering element in caring for homeless families is to strengthen parental competence and confidence. As Nunez and Collignon (2000) note, "The surest way to support homeless children's education is to support their parents" (p. 115). As parents complete GEDs, high school diploma programs, postsecondary education, and related job skills training, children

The Dynamics of Families Who are Homeless: Implications for Early Childhood Educators 
receive additional emphasis and modeling of the value of education. Furthermore, parents' increased economic and educational skills can lead to an improved quality of life for the family (Swick, 1997). Of course, such services need to be secondary to assistance in meeting families' emergency needs.

Empowerment Strategies for Supporting Homeless Families

Empowerment interventions should focus on supporting homeless families in resolving issues and stressors they see as impeding their functioning (Nunez, 1996). Two examples will illustrate how this empowerment process helps many homeless families address the difficulties they face.

Quint (1994) tells how one school used an on-site family service scheme to help one mother attain permanent housing along with a job, providing stability for her family. The school counselor and a social worker guided the mother in her interactions with the job placement staff and helped her successfully negotiate the housing agency process. They also provided essential follow-up support so that the gains could be sustained and expanded.

Toth (1997) describes how the placement of a foster child who had been in four homes in one year with a stable family altered the child's attitudes toward life in a powerful way. The family eventually adopted the child, thus providing the security and continuity the child needed to gain a sense of competence. The child's school performance improved, and he also benefited from more positive peer relations and increased self-esteem.

Here are three further examples of how early childhood programs can nurture families toward more positive living:

- A preschool center for homeless children and their families ensures that all of the children have a special place at the center where they can develop their sense of security and love. Parents are also helped to feel valued and special.

- An early childhood program for families in abusive situations helps each parent to learn how to take pride in themselves and their children. Parents are encouraged to make and display collages of the things they value the most in their lives. Each parent also develops a plan to strengthen themselves to be more nurturing, positive, and supportive in their relations with their child.

- An elementary school uses a "buddy" program to match children who are new to the school with caring peer mentors. Many of the children in this particular school are homeless or at-risk, and several of them eventually become mentors themselves. The "buddy" activities focus on helping children feel secure, important, and connected to their new school. Teachers and staff also act as mentors, often in informal ways with the parents.

Two additional and very important strategy areas are 1) helping families develop trust in each other and in their relations in the community, and 2) helping homeless families form mutually supportive relationships (Pipher, 1996; Swick, 2000).

The Dynamics of Families Who are Homeless: Implications for Early Childhood Educators 
Promoting trust among families further strengthens their social and emotional skills (Swick, 1997). Early childhood educators can model trusting relations with parents and children, providing a supportive environment in which parents learn about having positive and trusting relations with their children. One parent who participated in a focus group for homeless mothers said, "This program has really helped me turn my trust issues toward the positive, helping me see the best in myself and, thus, in my child."

Families who are homeless also need to have mutually supportive and responsive relations with each other, thereby enabling them to view each other in positive ways (Swick, 2000). Early childhood educators can support families in this process by:

- Encouraging families to recognize and support each other's strengths

- Complimenting parents on their positive interactions with their children

- Including parent-child social learning activities in every aspect of the program

- Encouraging families to use appropriate conflict resolution strategies

- Nurturing in families the importance of open and continuing communication with each other.

Early childhood educators can positively affect the lives of children and families who are homeless or in other high-risk situations. By understanding the dynamics of what homeless families experience, we can be more responsive to the challenges impeding their functioning. For example, family literacy and adult education strategies have been successful in empowering parents, both educationally and economically. Providing basic services like child care and transportation can make a powerful difference in how families work and interact in the world. Educators need to realize just how powerful we can be in using the early years of the family's life as a time to strengthen them--thus preventing homelessness or other "housing-distressed" situations, or helping families gain the power to resolve their homeless situation.

\section{References}

Anooshian, L. (2000). Moving to educational success: Building positive relationships for homeless children. In J. Stronge \& E. Reed-Victor (Eds.), Educating homeless students: Promising practices. Larchmont, NY: Eye on Education.

Ayers, W. (1997). A kind and just parent: The children of juvenile court. Boston: Beacon Press.

Bassuk, E. (1991). Homeless families. Scientific American, 265, 66-74.

Bassuk, E., Browne, A., \& Buckner, J. (1996). Single mothers and welfare. Scientific American, 275(4), 60-67.

The Dynamics of Families Who are Homeless: Implications for Early Childhood Educators 
Bellamy, C. (2003). The state of the world's children 2002. New York: United Nations Children's Fund.

Berck, J. (1992). No place to be: Voices of homeless children. Boston: Houghton Mifflin.

Buckner, J., Bassuk, E., \& Zima, B. (1993). Mental health issues affecting homeless women: Implications for intervention. Journal of Orthopsychiatry, 63(3), 385-399.

Bronfeubrenner, U. (1979). The ecology of human development and learning. Cambridge, MA: Harvard University Press.

Coontz, S. (1995). The American family and the nostalgia trap. Phi Delta Kappan, 76(1), K-1-K20 .

Dail, P. (1990). The psychosocial context of homeless mothers with young children: Program and policy implications. Child Welfare, 69(4), 291-307.

De Angelis, T. (1994). Homeless families: Stark reality of the 90's. American Psychological Association Monitor, 1, 38.

Edin, K., \& Lein, L. (1997). Making ends meet: How single mothers survive welfare and lowwage work. New York: Russell Sage Foundation.

Heflin, L. (1991). Developing effective programs for special education students who are homeless. Reston, VA: Council for Exceptional Children. (ERIC Document Reproduction Service No. ED 339 167)

Heyman, J. (2000). The widening gap: Why America's working families are in jeopardy and what can be done about it. New York: Basic Books.

Morris, J. (1998). Affiliation, gender, and parental status among homeless persons. The Journal of Social Psychology, 138(4), 241-271.

National Coalition for the Homeless. (1999). Why are people homeless? NCH Fact Sheet \#1. Washington, DC: Author.

Nunez, R. (1996). The new poverty: Homeless families in America. New York: Insight Books, Plenum Press.

Nunez, R., \& Collignon, K. (2000). Supporting family learning: Building a community of learners. In J. Stronge \& E. Reed-Victor (Eds.), Educating homeless students: Promising practices (pp. 115-134). Larehmont, NY: Eye on Education.

Peled, E., Jaffe, P., \& Edleson, J. (Eds.). (1995). Ending the cycle of violence: Community responses to children of battered women. Thousand Oaks, CA: Sage.

The Dynamics of Families Who are Homeless: Implications for Early Childhood Educators 
Pipher, M. (1996). The shelter of each other: Rebuilding our families. New York: G.P. Putnam's Sons.

Powell, D. (1998). Reweaving parents into the fabric of early childhood programs. Young Children, 53(5), 60-67.

Quint, S. (1994). Schooling homeless children. New York: Teachers College Press.

Shane, P. (1996). What about America's homeless children? Thousand Oaks, CA: Sage.

Stronge, J. (2000). Educating homeless children and youth: An introduction. In J. Stronge \& E. Reed-Victor (Eds.), Educating homeless students: Promising practices (pp. 1-20). Larchmont, NY: Eye on Education.

Swick, K. (1997). Strengthening homeless families and their young children. Dimensions of Early Childhood, 25(2), 29-34.

Swick, K. (2000). Building effective awareness programs for homeless students among staff, peers, and community members. In J. Stronge \& E. Reed-Victor (Eds.), Educating homeless students: Promising practices. Larchmont, NY: Eye on Education.

Swick, K., \& Graves, S. (1993). Empowering at-risk families during the early childhood years. Washington, DC: National Education Association.

Toth, J. (1997). Orphans of the living: Stories of America's children in foster care. New York: Simon \& Schuster.

Vissing, Y. (1996). Out of sight, out of mind: Homeless children and families in small-town America. Lexington, KY: The University Press of Kentucky.

Vissing, Y., \& Diament, J. (1997). Housing distress among high school students. Social Work, 42(1), 31-42.

Wasson, R., \& Hill, R. (1998). The process of becoming homeless: An investigation of femaleheaded families living in poverty. Journal of Consumer Affairs, 32(2), 320-332.

Kevin J. Swick is Professor Early Childhood Education, College of Education, University of South Carolina, Columbia.

Copyright 2004 Gale Group, Inc. ASAP Copyright 2004 Association for Childhood Education International

The Dynamics of Families Who are Homeless: Implications for Early Childhood Educators 